City University of New York (CUNY)

CUNY Academic Works

Publications and Research

CUNY Graduate Center

2012

\title{
The Social Life of Musical Instruments
}

Eliot Bates

CUNY Graduate Center

\section{How does access to this work benefit you? Let us know!}

Follow this and additional works at: https://academicworks.cuny.edu/gc_pubs

Part of the Ethnomusicology Commons, and the Music Performance Commons

\section{Recommended Citation}

Bates, Eliot, "The Social Life of Musical Instruments" (2012). CUNY Academic Works.

https://academicworks.cuny.edu/gc_pubs/486

This Article is brought to you by CUNY Academic Works. It has been accepted for inclusion in Publications and Research by an authorized administrator of CUNY Academic Works. For more information, please contact AcademicWorks@gc.cuny.edu. 


\title{
The Social Life of Musical Instruments
}

\author{
Eliot BATES / Cornell University
}

$A$ ccordion Crimes, a novel by E. Annie Proulx, traces the life of and routes travelled by a green diatonic button accordion: its birth in Sicily in the workshop of "The Accordion Maker," its numerous changes of ownership in the Americas during encounters between various immigrant communities, and its death when it finally falls into disrepair in the town of Old Glory, Minnesota. There are other accordions in the book, and many temporary human owners, but it is one particular green accordion that is the book's protagonist. We meet and experience other characters largely through their interactions with the green accordion, a character whose voice, we learn, "sounded hoarse and crying, reminding listeners of the brutalities of love, of various hungers" (Proulx 1996:22). This green accordion is not only central to human social networks, but is also itself an actor with agency. Seeing the extent to which Proulx's human characters succumb to ill fate (while the accordion lives on), it would not be a stretch to suggest that the green accordion was one of the only characters with agency.

A similar plot surrounds the protagonist of François Girard's movie The Red Violin (1998). In this story, the violin-maker Nicolò is about to varnish a violin he considers to be his best yet, when he learns that his wife Anna has died while giving birth to what would have been their first child. He mixes Anna's blood in with the varnish, donates the instrument to an orphanage, and never makes another violin again. The red violin, a fictional instrument inspired by Stradivari's 1721 "Red Mendelssohn," travels to Vienna, England, China and finally Canada, cultivating fatal host-parasitic relations with each violinist that it possesses, while motivating other individuals to steal it, sell it, or otherwise turn to morally evil behavior.

The Red Violin was not the first fictional account of a Stradivari violin capable of travel and the occult; J. Meade Falkner's novel The Lost Stradivarius (1895) features a fine Stradivarius which calls up the ghost of its original owner as it travels from England to Italy. Through much of the book, the violin is

(C) 2012 by the Society for Ethnomusicology 
depicted as being played by the protagonist's brother, but as the instrument progressively deepens its possession of the brother we become unsure about the relationship between the two. In the penultimate scene, the possession complete, our protagonist recounts:

As I opened my bedroom door the violin ceased suddenly in the middle of a bar. Its last sound was not a musical note, but rather a horrible scream, such as I pray I may never hear again. It was a sound such as a wounded beast might utter. (Falkner 1895:chapter 15).

I draw on these literary and fictional examples from North American and Western European literature to demonstrate the ease with which we can conceive of musical instruments as not only having some degree of agency, but even as protagonists of stories-as actors who facilitate, prevent, or mediate social interaction among other characters. ${ }^{1}$ In none of these stories is the violin or accordion symbolic, nor is the instrument unambiguously a metaphor or parable for obsession, evil, jealousy, or other problematic moral-emotional states. Let us not overlook the fact that the accordion and the two Stradivari stumble into social worlds that are preconstituted as sites of conflict and moral corruption. Furthermore, the instrument-maker, in these three stories, is not an evil magician who uses the instrument to manipulate other humans. The instrument is not the maker's doppelgänger, but instead more akin to the maker's golem, albeit a golem that works not through direct violence but rather by creating desire and affect through soundings. ${ }^{2}$ Yet, only some instruments seem to possess a golem-like autonomy. Guitars seem to have a propensity to teach their owners how to play them, ${ }^{3}$ gods live in or are channeled through certain instruments, and other instruments such as the Anatolian saz (which I will explore, along with Central Asian long-necked lutes, later in this essay) mediate interpersonal disputes in communities. Still other instruments seem (at least as far as we know) to have little agency.

In this article, I argue for taking objects, and particularly musical instruments, seriously_but not simply as things that humans use or make or exchange, or as passive artifacts from which sound emanates. Much of the power, mystique, and allure of musical instruments, I argue, is inextricable from the myriad situations where instruments are entangled in webs of complex relationships-between humans and objects, between humans and humans, and between objects and other objects. Even the same instrument, in different sociohistorical contexts, may be implicated in categorically different kinds of relations. I thus am arguing for the study of the social life of musical instruments. 


\section{Organology}

Mention organology to an ethnomusicology student, and what probably first comes to mind are museums, the Hornbostel-Sachs classification system, and perhaps (depending on the university program) a seemingly outdated class on measuring and documenting physical objects. This is not surprising: such legacies abound in many organology courses, scholarly articles, and institutions such as the Musical Instrument Museum (MIM) in Phoenix, Arizona. Instrument museums are mausoleums, places for the display of the musically dead, with organologists acting as morticians, preparing dead instrument bodies for preservation and display. Visitors to MIM walk by a glass display case containing a Turkish saz and hear a commercially available recording of saz music through their FM-equipped headsets. Yet, the display (like many displays in the museum) reads simply "Saz. Turkey. Long-necked lute," bereft of stories about the particular instrument, how it came to be in the museum, or its pre-death life in the hands of living players. ${ }^{4}$ Instruments may be central to curatorial work, but it is a different sort of organology that I have in mind.

The lengthiest chapter of The Ethnomusicologist suggests a symbolic classification for musical instruments. Ki Mantle Hood was attracted to the Hornbostel-Sachs system (1961) and preceding Mahillon system (1880) that was itself derived from the Natyasastra Sanskrit treatise, but found many of these systems' particular subdivisional choices to be arbitrary or inconsistent. He also believed that a classification system needed to take account of details such as the musical soundings and social function of the instrument, and developed the organogram as an experimental symbolic representation. To get a sense of Hood's ambitions, let's consider one of the few organograms that he details in full.

The notation indicates that the atumpan has the external and internal shape of a bowl opening into a cylinder made of (5) wood, has a single head fastened by a $\mathrm{H}$ (oop) $\mathrm{R}$ (ing) and is played with two crooked sticks, is used in pairs (the pair is called atumpan), is tuned by W(etting) the heads and by means of tuning pegs, supporting $\mathrm{V}$ lacing, to a $\mathrm{R}$ (elative) pitch of $\mathrm{H}$ (igh) and $\mathrm{L}$ (ow). The drums are held in a slanting position by a stand. The pair has the following Hardness Scale ratings: Loudness, 8; Pitch, 3; Quality, 4; Density, 7-9; Technique, 4; Finish, 1; Motif, 4. They are associated with a $\mathrm{G}$ (roup) of $\mathrm{H}$ (igh) social status that values them at 10 , they $\mathrm{S}$ (ymbolize) the soul of ancestor drummers and a tree, are honored with L(ibations), have magic $\mathrm{P}$ (ower), and $\mathrm{R}$ (itual) is involved in their manufacture and when they are played. S(ociety) values them at 10 , the $\mathrm{P}$ (layer) values them at 10 , the $\mathrm{M}$ (aker) of the drums is accorded a special $\mathrm{S}$ (tatus), their $\mathrm{M}$ (onetary) value is 8 , they are indispensable in the life C(ycle) of man. (Hood 1982:155-6)

In addition to construction details and considerations of the interface (how performers play, tune, or otherwise modify the drum's soundings), Hood's or- 
Figure 1. Mantle Hood's organogram for Ghanean atumpan drums.

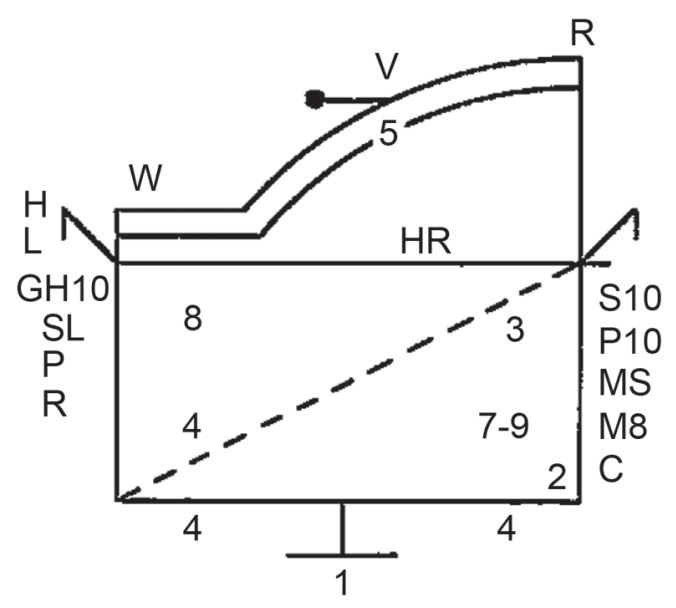

ganograms show concern for ornamentational details (finish or motif), instrumental soundings (loudness, pitch, and quality), and basic aspects of the instrument's relationships to individuals and to society. While richer than preceding classificatory systems, Hood's organograms don't convey the dynamic and variable nature of personal and societal relations with instruments, and the inconsistent depth of his accompanying narratives ultimately results in a somewhat incoherent concept of the instrument-object (following on Ian Woodward's insistence that "it is stories and narratives that hold an object together, giving it cultural meaning" [2009:60]). Organograms may have been relegated to the dustbin of ethnomusicological history, but I do wish to underscore that at the very least the creation of an organogram required contextual information that could only come via ethnography. ${ }^{5}$

Outside of organology journals, ${ }^{6}$ perhaps the last significant plea for a broader study of instruments surfaced in the 1990 issue of UCLA's Selected Reports in Ethnomusicology, edited by Sue DeVale. For DeVale, organology's ultimate purpose was "to help explain society and culture" (1990:22), and instruments might even contain the "essence of society and culture" (ibid.). She surveys the scope of prior work and suggests classificatory, analytic, and applied approaches to organology, and zones of crossover between those three approaches. Yet, none of the other articles in the special issue come as close as DeVale to suggesting a mandate for thinking through instruments. Buried in the article, DeVale recalls two examples from her own research, including a theory of instrument-spirits as participants in rituals (DeVale 1988) and the life story of the gamelan brought to Chicago's Columbian Exposition in 1893. The former example focuses our attention on different possible subject/object 
relations between the scholar, instrument, performers, and society. The latter calls to mind the narrative of Accordion Crimes and reiterates the potential specificity of organological study: sometimes one specific instrument is embroiled in unique stories, trajectories, and sets of social relations.

Many of DeVale's organological mandates were prefigured by five decades in Robert Van Gulik's The Lore of the Chinese Lute, a work that was influential on Chinese music scholarship but less so on organology. ${ }^{7}$ Van Gulik concludes that the ch'in (qin) works as a "symbol of literary life" ([1940] 1969:17) through its aesthetics (having elegant physical features), its resistance to becoming popular (from theoretical and practical factors), its expense and rarity, and in how the elegant taste required to appreciate ch'in music hints at the unusual sociability of the instrument. The ch'in's ontology as a musical instrument distinguishes it from other antique objects, as the ch'in alone is capable of giving "an impression of meeting with the ancients in person" (ibid.:18).

The numerous ch'in-pu (qinpu), handbooks for lutenists, comprise a primary source type for Van Gulik. They contain striking details about instrument and string construction, playing techniques, the "discipline of the lute player" (ibid.:32), and the "ideology of the lute" (ibid.:33). Concerning lute ideology, Van Gulik writes: "it is suited for harmonizing the human mind, and may move man to the improvement of his heart" (ibid.:72). In addition to discussing musical techniques and the effects of lute playing on the literati and society, several handbooks included detailed descriptions of how the lute should be accompanied by other objects and in which acoustic environments lutes should reside. One handbook stipulated: "There should be a flywhisk, a sonorous stone, brushes and ink to keep the lute company and there should be lustrous flowers and cranes to be its friends. All these things belong to the domain of the lute" (ibid.:69-70). Another noted the need for a special room in the lutenist's house for playing, and described the material construction and acoustic qualities of such a room (ibid.:67). Beyond human-object sociability, several stories discussed the effect of ch'in playing on birds (cranes in particular), and one recounted how a crane taught a master ch'in player a song that, subsequently performed for a duke, led to an awe-inspiring sequence of events including the summoning of a storm and an ensuing drought that lasted for three years (ibid.:143-44).

While instruments appear to be in the margins of ethnomusicological inquiry in the early twenty-first century, ${ }^{8}$ several notable works have emerged since $2000 .{ }^{9}$ Regula Qureshi and Kevin Dawe provide cogent arguments for studying the embodied affect and symbolic and affective meanings of musical instruments. In an article on Indian sarangis and sarangi players, Qureshi explores the interrelations between audible aesthetics, instrumental symbolisms, and debates about the appropriateness of certain performance contexts for sarangi playing. 
She notes the absence of a political dimension in scholarship on emotion and embodiment in music:

To insert music into [the anthropological debate on the politics of emotion] requires a more broadly based and widely referenced notion of music and its production. It calls for a willingness to expand music studies from their cocoon of conventionalized aesthetic and sonic jouissance in order to allow political and historical implications to surface and thus to hear when music (and its instruments) speak to social struggle and to the politics of dominance and exclusion. (2000:808)

Qureshi's work was the first to connect anthropological studies of the body and embodiment to the domain of musical instruments and instrumental soundings. However, one conclusion that could be drawn from her article is that contested meanings of the sarangi are a direct result of the web of associations and meanings in which sarangis are encountered in Indian society-"an unequal, exploitative feudal and increasingly capitalized class structure" (ibid.:830). This is a minor distinction, perhaps, but I will return later to the difference between casting an instrument as the subject or as the object of the research.

Kevin Dawe, whose field research in Crete focused on a small indigenous fiddle called the lyra, extends a common ethnomusicological proverb in urging us to conceive of musical instruments as culture:

They exist in webs of culture, entangled in a range of discourses and political intrigues, and they occupy engendered and status-defining positions. Musical instruments are seen as material and social constructions. (2007:114)

His work is strikingly heterogeneous in the scope of its ethnographic observations: festivals, lyra-makers, lyra amplification, the visibility of lyras in contemporary Crete, and even villagers who play "air lyra." In addition to his discussion of lyra meanings, Dawe writes about instrument pedagogies and the bodies of lyra performers. He suggests that "musical instruments can transform minds and bodies, affecting states of mind as much as joints, tendons and synapses, ergonomics and social interaction-the joy of playing musical instruments is a joy that comes from exhilaration felt at physical, emotional and social levels" (Dawe 2005:60). This assertion is one of the few in music scholarship, following DeVale, where instruments are regarded as potential subjects (rather than objects) of research, a tantalizing suggestion that there might be a broader valence to the sorts of fictional accounts of instruments I began with in this article, or a value in what might be called "thinking through instruments."

Yet, while the lyra "and its repertoire have evolved with, and are inextricably linked to, the intricate rituals, spectacle, and display of the celebration" (Dawe 2007:115), Dawe's work stops short of maintaining a sustained analysis of the lyra as an active participant in those rituals, spectacles, and celebrations. He hints of the transformative power of instruments, and writes elsewhere of instruments as "active in the shaping of social and cultural life" (2001:220), but 
most of his analysis is of the "polyvalent and polysemic" (ibid.:222) meanings of lyra in contemporary Cretan society. The lyra and the lyra-maker's shop become sites where broader social processes (technological modernization, globalization, gender politics) can be witnessed; the subject of the article shifts to Cretan society, the lyra becoming a prosthesis of politics (specifically, the body politic) rather than the central actor. ${ }^{10}$ Dawe writes of the considerable economic value of the lyras made by Dimitris Agrimakis, one of the last great makers, and about changes to the pegs and headstock of the instrument. But rather than analyzing Dimitris's relation with lyra materialities during the construction stage, Dawe treats the passive, inert lyras adorning the shop window as a metaphor for social change. I, too, find it productive to investigate how instruments become such contested sites of meaning, and how instrumental sound can come to profoundly affect and transform people. However, I assert, many valences of instruments go beyond meaning, symbol, and metaphor. ${ }^{11}$

\section{Central Asian Long-Necked Lutes}

Ever since Mark Slobin's studies of music in the social life of Kyrgyzstan (1969) and Northern Afghanistan (1976), long-necked lutes have had a significant place in scholarship on Central Asian music. Slobin devotes several pages to the construction, playing technique, and ethnic variations (Uzbek and Turkmen) of the dutār, and documents changes to the instrument when it moved from being a rural instrument to one played in towns and cities. Building on this work, John Baily wrote extensively about the dutār in the city of Herat, discussing innovations in instrument construction, instrumental kinesthetics, and the "complex and dynamic sociomusical situation which involves changes in music structure and changes in the social position of music and musicians" (1976:53-54).

Baily was one of the first ethnomusicologists to conduct a lengthy study of the kinesthetics of playing in relation to the morphology of the instrument. ${ }^{12} \mathrm{He}$ documents the shift from a left-hand technique initially learned through visual information to a later kinesthesis honed through increased "auditory control of the performance" (1977:309). For Baily, the relation between kinesthesis and morphology directly influences the nature of musical genre: "While classical music may be highly compatible with the spatial layout of the rebab, traditional Herati music is not. This shows how closely these two kinds of music are adapted to the instruments on which they are habitually played and suggests that in both instances the instrument has to some degree shaped the music" (ibid.:323). Baily argues that physical changes in the dutār "have a significance that extends far beyond their interest from the point of view of material culture. They express in a concrete manner the essence of a complex and dynamic sociomusical situation which involves changes in music structure and changes in the social position 
of music and musicians" (1976:53-54). In a later work, he asserts the representational power of the dutār as the "voice" of Herat, contributing to Herat's role "as an integral part of Afghanistan" (1988:158).

Two scholars have written about the Ahl-i Haqq tanbùr, an instrument at the center of sacred and secular music practices of the Gorani Kurds of Western Iran. Partow Hooshmandrad advocates for a lived organology (2004:42) based on stories, historical meanings, and analysis of the function of musical instruments in human-divine relations. She writes this about the "sanctity and sacred function of the tanbūr":

Tanbūr is an embodiment of various aspects of the Ahl-i Haqq religion. It secretly holds the divine message of the presence of the divine; it is the instrument with which the sacred musical repertoire of the Ahl-i Haqq is performed and the sacred texts are sung. It may be used in the sacred ritual of Jam where, even when it is not sounded, it is considered as a Jam'Nishin and receives a portion (bash) of the sacred blessed food. It is greeted by kissing in the Jam and when approached in general. It heals illnesses, and is hung in the best part of an Ahl-i Haqq's home as a sacred icon with a constant purifying effect. Most importantly, tanbür is a manifestation of one of the Haftan. (Hooshmandrad 2004:25)

One of the most striking moments in Hooshmandrad's dissertation is her analysis of the enormous production output of the living master of tanbūr-making, Ustād Asad Allāh. Even though the Ahl-i Haqq community in Gahwārah numbered fewer than 15,000, Ustād Asad Allāh had produced perhaps upwards of five thousand instruments, and demand appeared to be steadily increasing. The tanbūr, which had always been important in Ahl-i Haqq households, proliferated in the aftermath of the Islamic revolution. Many instruments ended up inhabiting museums and Sunni and Shía households; fifty instruments had even travelled to private homes in the U.S. Yet, unlike other Iranian stringed instruments, the price of the tanbür was stable, largely since the $p \bar{i} r$ (religious/community leader) strove to avoid the commoditization of the instrument (ibid.:45-48) or a situation where an Ahl-i Haqq could not afford to own the instrument. The tanbūr in this account is a central actor-in the continuation of a minority religious practice in the face of changing national religious politics; in a form of commerce that resists supply and demand economic logics; in the social relations between the community leader, instrument makers, and the local and regional Ahl-i Haqq communities; and as a mediator in relations between the Ahl-i Haqq and outsiders.

Navid Fozi (2007) extends Hooshmandrad's work, providing a detailed ethnography of tanbūr-making techniques focused on the bodily and knowledge practices of Ustād Asad Allāh (written as Ostád Asadulláh Farmáni). Fozi's theoretical framework attempts to reconcile a Maussian approach to the body as a "natural instrument" and "technical object" with Barth's approach to studying distributed knowledge. A key point for Fozi is the delineation between processes where makers verbally articulate why they use particular tools or 
techniques, and conventions of the craft that seem to defy utilitarian explanations. His account of bodily techniques and knowledge practices gets to the heart of the complexity of tanbūr-making and the transmission of knowledge between generations of makers. It also suggests the need for an embodiment paradigm attentive to bodily capabilities and instrumental techniques, rather than a Qureshi-style paradigm where bodies constitute a site for class struggle. However, I feel that Fozi's framework is less conducive to exploring certain liminal moments. Fozi observed that makers don't measure the dimension of a bowl that they are carving, instead determining its dimensions "through intuition," and that they routinely add little pinholes in the side of the tanbūr that have no clear audible effect or symbolic function. It is precisely these moments that show the limits of an exclusive focus on body techniques and articulated knowledge, and the perils of focusing exclusively on the human side of human-instrument interactions. In neighboring Turkey, ' $\hat{u} d$ makers talk of letting the wood "tell them what to do," a phrase I have heard articulated by wood turners in the San Francisco Bay Area. Perhaps a similar attention to wood, to the proto-tanbūr, is at work in Iran, too.

The instrument narratives of Van Gulik, Qureshi, Dawe, Baily, and Fozi in sum, hint at other possible valences of Hooshmandrad's "lived organology." I think this can be pushed further, particularly if the subject is shifted to the tanbūr-not such a stretch if we recall that organology is nominally the study of instruments. The tanbūrs of Hooshmandrad and Fozi mobilize publics around them. They mediate relations between pir, makers, and consumers, yet do so without constructing a market based on supply and demand. Tanbūrs only come into being if there are makers willing to undergo physiological and psychological pedagogies, makers who cultivate particular bodily skills and knowledge sets yet never attain a complete knowledge about tanbūrs (while being willing to adorn the instrument in ways that have no pragmatic purpose nor result from any known symbology). The tanbūr used the Iranian Revolution of 1979 as an opportunity to further its own proliferation: post-Pahlavi tanbūrs serve myriad symbolic-ornamental functions, adorning the walls of Ahl-i Haqq homes and those of non-musician consumers alike, and populating museums around the world. And we haven't even touched upon tanbūr soundings, tanbūr players, or the tanbūr's role in healing the Ahl-i Haqq.

\section{The Social Life of Objects}

In short, I am arguing for a paradigm that encompasses the full range of possible human-object-divine relations, as seen in instrument making, performance, musical healing, and numerous other domains. Earlier I used the phrase the "social life of musical instruments," which we should revisit in light of the intriguing possibilities opened up by tanbūrs, dutārs, and ch'ins. But 
first, a clarification: in referencing the "social life of objects" or "political life of objects," I am not suggesting a utilitarian/semiotic approach such as that of Stephen Riggins, where "the social life of objects is a response to complexity in the social life of persons" (1994:20), or something akin to Arjun Appadurai's "perspective on the circulation of commodities in social life" where "what creates the link between exchange and value is politics" (1986:3). In neither approach is the material object the object of study; rather, the object world is simply another instantiation of a preconstituted humanistic theoretical terrain or economic system, the objects rendered immaterial. ${ }^{13}$ There is a difference between musical instruments being incidental to, or constitutive of, social interaction.

The loose assemblage of approaches that I find to be most useful originates in Science \& Technology Studies (STS) and in recent anthropological and political science work on material culture. ${ }^{14}$ STS, which like ethnomusicology is a fieldwork-based ethnographic discipline, has produced much work on invention and technological adoption (e.g., Bijker 1995) and the practices of laboratory work (e.g., Latour and Woolgar 1979). Several STS works have explored musical technologies, including failed innovations in European classical instrument design (Bijsterveld and Schulp 2004), the shifts in manufacturing of audio recording technologies (Théberge 1997), and the invention of the Moog synthesizer (Pinch and Trocco 2002; Pinch 2008). In contrast, much of the new materialism literature examines visual art (Gell 1998, and numerous articles inspired by Gell's approach) and material artifacts in everyday life (Miller 1998; Vannini 2009). What ties together these approaches is a shared concern with examining "the performative and integrative capacity of 'things' to help make what we call society" (Pels, Hetherington, and Vandenberghe 2002:2), and theorizing the social to include people, animals, material objects, spaces, and ideas/concepts.

These divergent approaches all depend upon an analytical "naivitae" when analyzing the relations between humans and nonhuman objects, and all tend to trifurcate complex entities into constituent parts (also called actors, actants, agents, objects, or vital matter), assemblages (also called networks, webs, ecologies, or societies), and relationality (also called sociality and semiotics). The most oft-used approach, Actor-Network Theory (ANT), loosely defines an actor as neither a subject nor object, but as a source of action, "something that acts or to which activity is granted by others. It implies no special motivation of human individual actors, nor of humans in general" (Latour 1996). ${ }^{15}$ Networks are simply ad-hoc groupings of heterogeneous objects, and relationality examines how these ad-hoc groups cohere. In conducting an ethnography of actor-networks, the key methodological challenge is in figuring out which objects are significant (and therefore part of an actor-network or material assemblage) and how they relate. 
Simply casting the net wider and including more objects in networks is, by itself, an unremarkable proposition. However, these approaches all share a theory of agency and power which has significant implications for humanistic scholarship: agency becomes not an inherent capacity held only by humans, but rather something "seen as differentially distributed across a wider range of ontological types" (Bennett 2010:9). In short, any material object, within any assemblage, has the same capacity for action. Political scientist Jane Bennett has written most extensively about this material agency, which she terms thing-power, "the curious ability of inanimate things to animate, to act, to produce effects dramatic and subtle" (ibid.:6). Bennett argues that we must "readjust the status of human actants: not by denying humanity's awesome, awful powers, but by presenting these powers as evidence of our own constitution as vital materiality. In other words, human power is itself a kind of thing-power" (ibid.:10).

One of long-standing critique of ANT and related approaches is that it ascribes intentionality to inert matter, but this is a misreading of the theory of agency as it conflates intention with effect. Lambros Malafouris, in a thoughtprovoking study of potters, clay, and potting wheels, argues that we must distinguish between a sense of agency and material agency, between prior intention (the potter planning to throw clay in a certain way) and intention in action (an ongoing feedback systems where potters respond by feel to clay). For Malafouris, "agency is about causal events in the physical world rather than about representational events in our mental world" (2008:30). Returning to Bennett:

Human intentions [are] always in competition and confederation with many other strivings, for an intention is like a pebble thrown into a pond, or an electrical current sent through a wire or neural network: it vibrates and merges with other currents, to affect and be affected. This understanding of agency does not deny the existence of that thrust called intentionality, but it does see it as less definitive of outcomes." (Ibid.:32)

An ANT or vibrant matter approach also raises important issues about how to analyze the temporality of networks, and more broadly how to theorize culture, context or community. ANT scholars write of the durability of networks - the tendency for some networks to stay similar in form over long periods of time, and durability is a key issue in the analysis of musical instruments that seemingly have produced similar effects for hundreds of years. Yet, we must always be attentive to differently structured networks around the same instrument type, and the multiplicity of networks that may include even one particular instrument. Allowing agency to material objects, and thinking of assemblages as ad-hoc groupings of heterogeneous objects, moves beyond a culture-context divide, as both culture and context are formed simultaneously with the ad hoc assemblages. ANT-informed scholarship could be viewed as being wholly about the formation of culture and context, or alternately as a 
mode where culture and context cease to be productive analytics. The networks of ANT can do analytical work similar to Will Straw's "scenes" (1991), but do so with a much greater degree of specificity with regard to the constitutive actors and actants. Musical instruments constitute a fruitful site for ANT-style approaches, as they are intertwined in myriad forms of social relations, and instrumentalists and audiences often have distinctively intimate affective relations with them.

\section{Encounters with Instruments}

It is not an exaggeration to state that instruments introduced me to ethnomusicology and created the initial framework for my study. I never consciously set out to theorize instruments, though I have been deeply involved in oud/ $u \hat{u}$ study and performance ever since a chance encounter in 1992 with Scott Marcus and one of his ouds lured me into the UCSB Middle Eastern Ensemble. ${ }^{16}$ Spending time in Turkey with oud performers, teachers, students, and makers provided an obvious variety of oud-specific observations, including divergent beliefs about what ouds were, what ouds evoked or invoked when played, or what potentially permanent physiological and moral effects oud playing might have on me or other players. For this article, though, I decided against an autoethnographic approach, with the oud as the focus of study, since my own trajectory as an oudist has been somewhat unconventional. More importantly, I feel too close to the oud to tease apart what is interesting or noteworthy about my relationship with it. ${ }^{17}$

For the remainder of this article, as an exemplar for my approach, I will attempt the beginnings of an analysis of the social life of the saz, today an ubiquitous instrument among Anatolian, South Caucasian, and Southeastern European ethnicities including Turkish-, Kurmanc1-, Zazaki- and Azeri-speaking Sunni Muslims and Alevi-Bektaşis. ${ }^{18}$ That the saz (also known as bağlama) is often called the "national" instrument of Turkey (Markoff 1993:96) attests to a certain kind of widely perceived importance, although as I will suggest, simply being a potential (albeit unofficial) national instrument doesn't immediately mean that the saz is symbolic of the nation, constitutes or embodies the nation, or even has a clearly conceived function in relation to society, regardless of how national borders might be drawn.

My own encounters with the saz span nearly twenty years, beginning in 1993 with my first ethnomusicological fieldnote, where I wrote in surprise about the thousands of sazes I saw being carried up and down İstiklal Caddesi (a busy pedestrian street in the Taksim neighborhood of Istanbul). My oud teacher Necati Çelik is also an excellent saz artist who plays in the style of Haci Taşan, and in lessons he would often demonstrate the intricacies of makams (melodic modes) shared between rural and urban art musics by playing Central Anato- 
lian folk music on the saz. However, it was when I started researching Istanbul's recording studios and arrangement practices that I personally experienced the inextricability of the saz from modern Turkish society. Although professional studio musicians specialize in one of over forty different Anatolian folk instruments (see Bates forthcoming), the saz is the only such instrument to be found on nearly every contemporary recording of arranged folk, arabesk, Turkish pop, and Kurdish popular music. I recorded numerous saz artists, ranging from rising stars (Özlem Taner, Engin Arslan, Erol Mutlu, Ali Riza Albayrak) to established professionals (Erkan Oğur, Çetin Akdeniz, Neşet Ertaş). Conversations with these and other artists revealed often contradictory attitudes towards a multitude of issues affecting music and instruments in contemporary society, including changes in saz making, pedagogies, playing techniques, and musical meanings and contexts. I pursued these contradictions through subsequent ethnographic observations of saz makers, performances (sacred and secular; in concerts, houses, bars and universities), pedagogy in private lesson houses, and in discussions of saz on Turkish social media websites.

In the subsequent tangle of anecdotes and observations, my goal is not to provide a comprehensive overview or theory of the saz, an instrument that (like most instruments) is grossly undertheorized. ${ }^{19}$ Rather, in order to explain the immense thing-power of the saz, I chose examples that demonstrate the heterogeneity of networks in which sazes have agency, and the multitude of attitudes towards and engagements with the saz. I hope to show how an approach that entails the study of heterogeneous networks including instruments, performers, makers, listeners, and other material objects directly addresses many key questions at the core of ethnomusicology, while extending the analytical models and methodological paradigms that we have available. I also hope that this article will encourage others to publish their own saz stories, to expand our understanding of the social life of the saz.

\section{Saz and Song}

"Ben Ağlarım Saz Ağlar" (As I cry, the saz cries) Şevki Bey

"Ben ağlarım saz ağlar" begins the song, which is not an unauthored türkü, but a newly composed şarkı by Istanbul-based composer and pedagogue Şevki Bey (1860-91). The phrase as it stands is ambiguous due to a missing preposition or converbial suffix. It might be interpreted as having a sequential causative relation, such as "when/if/every time I cry, the saz cries," or "when/if/every time the saz cries, I cry." However, with syllables missing, the phrase would most likely connote a simultaneity of singer and saz crying, folding subject (the singer) and object (the saz) into a unity that cries together. 
In the lyrics to many türkü (metered and unmetered Turkish-language folksongs of unknown authorship) and pedagogical şarkı (authored urban art music songs) such as "Ben Ağlarım Saz Ağlar," one finds copious mentions of sazes, saz strings (tel), broken sazes, saz frets (perde), saz tunings (düzen), and saz picks (mizrap or tezene). Sazes cry (ağlamak) and laugh (gülmek), although based on these words' sheer frequency alone, they seem to cry quite a bit more often than they laugh, and often, just like their owners, feel troubled (dertli). The listener in many songs is ordered to come to the saz or to the sound of the saz, but rarely to the saz player. When the aşı $k$ dies, ${ }^{20}$ the saz might be instructed to sing by the aşık's gravestone. Quite evocatively, when aşık Deli Hazım wants us to get to know the poet Karacaoğlan, he begins by proclaiming that the saz's strings act as an interpreter for us-perhaps not so surprising when we consider that many aşık songs correlate the effects of the saz with the words sung by the aşık (saz ve söz). Aşık Ali İzzet Özkan asks you to wish upon a saz string (teller de muradın alsin), but probably not the strings of the broken saz that Aşı Reyhani hung from the ceiling (kırılmıs sazımı astım tavana). But the saz loses control and is anthropomorphized when Dursun Ali Akınet's saz becomes "unfaithful," the frets "oppressive and cruel"; the saz-pick "pulls the trigger" and the string whacks him (saz vefasiz oldu perdeler zalim, mizrap tetik çekti tel vurdu beni). ${ }^{21}$ The saz alone appears in Turkish lyrics with such a strongly articulated agentive force and position. Even though the sound of the kemençe or tulum allegedly makes girls uncontrollably begin dancing, the kemençeci or tulumci (kemençe or tulum player) is assumed to be in control of the process. ${ }^{22}$

Yet I will return to the crying. One performer's saz seemingly makes audiences cry more often than others-the saz of Neşet Ertaş (b. 1938 or 1943). ${ }^{23}$ Neşet is a folk musician who performs the traditional repertoires of the Kırşehir region of Central Anatolia (particularly the unmetered bozlak form), and also an ozan (poet) who authored many notable new songs, and after his father Muharrem Ertaş (d. 1984) is considered the authoritative interpreter of bozlak. ${ }^{24} \mathrm{My}$ colleague Mustafa Avc1 recounted numerous stories where he was moved to tears from simply listening to the sound of Neşet's saz, in concerts and even when listening on headphones while riding in a dolmuş (personal communication, March 2011). On the popular social dictionary site Ekşi Sözlük, over ten authors wrote entries about crying while listening to Neşet Ertaş, some attributing the causality to Neşet's saz, others attributing it to Neşet himself. ${ }^{25}$ However, Neşet and/or his saz have a particular relation to performed repertoire. Respected saz artist and scholar Bayram Bilge Tokel famously said:

Neşet Ertaş, herkes gibi çalıp söyleyen sıradan bir sanatçı değil. Türküyü bağlamaya, bağlamayı türküye bu kadar yakınlaştıran ve yakıştıran. (Neşet Ertaş is not like others in the lineage of singers who play [the saz]. The türkü is brought closer to the bağlama, the bağlama to the türkü and each make each other look so good). (Tokel 2007) 
That the saz performer mediates between instrument and repertoire (türkü) is notable, especially in light of the lingering question of performer or instrumental agency. It leaves open the possibility, although one I must stress has not to the best of my knowledge been explicitly articulated, that an "unmediated" performance of türkü requires only saz and song, not the performer. Crying sazes and repertoire mediations, in actor-network terms, point to the need to be open to complex and potentially shifting agentive relations between performer, instrument, repertoire, and audience.

However, crying is not the only affective response to saz. Within Alevi communities, the saz has an essential position in the primary institutions of sacred and secular music-making: cem and muhabbet. ${ }^{26}$ In Cem TV's satellite broadcasts of public cem religious ceremonies, Alevi festivals, and semah dances, the saz has a strong visibility. However, the saz's importance doesn't solely come from its visual traces in transnational broadcasts. Within a lesser-known form of cem called görgü cemi, a ceremony used to mediate disputes within a community, saz ve söz is considered to be a key enabler of reconciliation, much as the tanbūr in neighboring Iran functions as a mediator between the Ahl-i Haqq and outsiders. ${ }^{27}$ Muhabbet is a less formal (but equally important) music performance context that transpires in Alevi homes. Muhabbet literally means "conversation," and Alevi muhabbets often unfold as a "dialogue" between participants-not a speech-based dialogue, but rather a combination of secular songs (deyis, nefes) interspersed with instrumental performance. Again, the saz is essential to muhabbet, a key actor in the dialogue, and an enabler of a social atmosphere of equality and togetherness (personal communication, Sabahhat Akkiraz, 19 May 2007).

\section{Saz and Nation}

The saz has been called the national instrument of Turkey. ${ }^{28} \mathrm{~A}$ competing cultural identity claim affiliates the saz with Alevi sacred/secular practices and thereby Alevism as an ethnicity and Alevi-Bektaşism as a religion. In many claims, justification originates in the instrument's alleged Central Asian origins in a longnecked lute called the kopuz, although it is equally plausible that sazes (or perhaps both the saz and the kopuz) derive from long-necked lutes that are known to have existed in nearby Mesopotamia since at least the Akkadian Era (c. 2350 to 2170 BCE; see Turnbull 1972). Whether one history is more accurate, or whether both are wrong and some other origin of the saz is speculated, is of little importance for our purposes. Instrumental here is that in each version the saz is described in terms that would typically be used to historicize an entire nation-it has a history and a prehistory, a stake to a territorial claim, and a social identity. The codified tavir system of regional performance practices (see Markoff 1986a and Bates 2011) and repertoire of theorized saz ornaments now used in Turkish conservatories 
and private lesson-houses even suggests, if somewhat obliquely, that the saz has its own language distinct from the languages of other instruments. ${ }^{29}$

We can perhaps best relate the Turkish-national nature of the saz to the efforts of Ankara Radio (later, Turkish Radio and Television) in conducting folklore expeditions, bringing aşı poets to the studio, arranging collected folk songs for ensembles, and subsequently broadcasting arranged folkloric performances on national radio and TV. It was through programs such as Yurttan Sesler (Sounds of the Homeland), first broadcast in the 1940s, that the nation as a whole became aware of the music of localities and regions other than those in which they lived, and the saz was the core instrument in the Yurttan Sesler ensemble and subsequent national and regional governmental folk music ensembles. While most rural Anatolian music had been traditionally performed solo or with twoto three-instrument ensembles, Turkish governmental ensembles from Yurttan Sesler onwards featured four or more different-sized members of what became known as the saz family of instruments. ${ }^{30}$

One of the most cogent examples of sazes mobilizing a public was an event first staged in Köln, Germany in 2000 (later in Istanbul) called "Bin Yllın Türküsü" (one thousand years of Turkish ballads), where 1246 sazes, 674 semah dancers, and the Köln Symphony Orchestra took the stage. The event was sponsored by the German Alevi Federation of Associations, and transpired first as a performance by and for the Alevi-Turkish diaspora living in Germany. While the event's name underscores the historicity of Turkish-language folk ballads and hints at a Turkish national claim, much stronger is an Alevi national claim, as semah sacred/secular dancing and much of the performed repertoire, notably songs such as "Ötme Bülbül Ötme," are specifically meaningful to Alevis. Yet, the event transpired "in the diaspora," in a country where Turkish nationals comprise the overwhelming majority of guestworkers, suggesting a reading of the event as an instantiation of an Alevi and/or Turkish nation within Germany. Further complicating things, some accounts of the event positively emphasized the participation of twelve African and five Greek performers, suggesting that brotherhood in an international sense was one possible message of the event. Getting 1246 sazes and 1246 saz players on one stage (and in tune) was a massive undertaking, yet even such a clear instantiation of an instrumentally mobilized public had an ambiguously symbolic, or perhaps polysemic, valence. Still, no other instrument would have had such a powerful mobilizing force in that context.

\section{The Material Saz}

The Hornbostel-Sachs classification of the saz is either 321.321-5-6: "Necked bowl lutes, carved, sounded with the bare fingers or sounded by plectrum," or 321.322-5-6: "Necked bowl lutes or necked guitars, whose body is built up in the 
shape of a bowl, sounded with the bare fingers or sounded by plectrum" (Hornbostel and Sachs 1961:23). These classifications define the saz as functionally/ structurally identical to instruments as diverse as the guitar, mandolin, theorbo, Ottoman or Uzbek tanbur, Herati dutār, Okinawan sanshin, and American or West African banjo. The Hornbostel-Sachs system was not intended to classify the specificity of unique instruments, but rather to highlight commonalities across the world of instruments. This system focuses the museum curator's attention on aspects of the instrument perceived to be essential for the production of musical sound, which hints at certain kinds of codified relations that curators or collectors might have with instruments. ${ }^{31}$ This mode of organological thought downplays the ornamental conventions of instruments; that a tassel often hangs from a saz's pegblock, or that saz makers carve their insignia in the rosette covering the instrument's sole soundhole becomes immaterial.

However, I mentioned two possible classifications, differing only with regard to bowl construction technique. Oddly, it is not clear in what way building up material into the shape of a bowl, versus carving a bowl out of a single piece of wood, necessarily results in a different sound. This distinction could be viewed as simply ornamental, but we'll take advantage of this possible slippage in classical organological taxonomy to explore a distinction that has profound implications in the world of saz-making, after a detour into saz workshops and factories.

According to saz-maker Özbek Uçar and many others, the traditional means for making a saz entailed carving out a bowl from a single piece of wood-a reductive process of removing material to leave form. ${ }^{32}$ A newer staved-bowl technique entails carefully bending thin strips of wood around a bending iron and then gluing them together to form a bowl-like form, a process of adding material to fabricate form. Additive or reductive processes, with hand tools versus electric ones, imply different relations between saz-maker, tool, wood, and the semi-finished proto-saz object. The staved bowl technique was cultivated in the craft guilds that specialized in oud- and tanbur-making, notably the multigeneration workshops of the Manol and Karibyen families, but became a mode of saz construction only in the mid to late 1900s. For that matter, sazes weren't made en masse in workshops until well after the founding of the Turkish Republic. Historically, saz players themselves mades sazes, parts sourced from local trees.

Two famous saz players, Pir Sultan Abdal (see the next section) and Aşık Veysel (1894-1973), both played sazes carved out of chestnut or mulberry wood (Figure 2). Today, the carved mulberry/chestnut saz is the iconic saz for Alevis, and handcarved sazes command a premium over staved ones. In part, prices derive from the limited availability of chestnut and mulberry wood, as it is illegal to cut chestnut and mulberry trees in Turkey and makers are dependent upon infrequent occasions when municipalities cut or prune trees and make wood available to luthiers. ${ }^{33}$ Also, handcarving a bowl from mulberry is laborious and 
Figure 2. Etching of Aşık Veysel playing a carved saz, in Özkek Uçar's saz atölye. Photograph by Ladi Dell'aira.

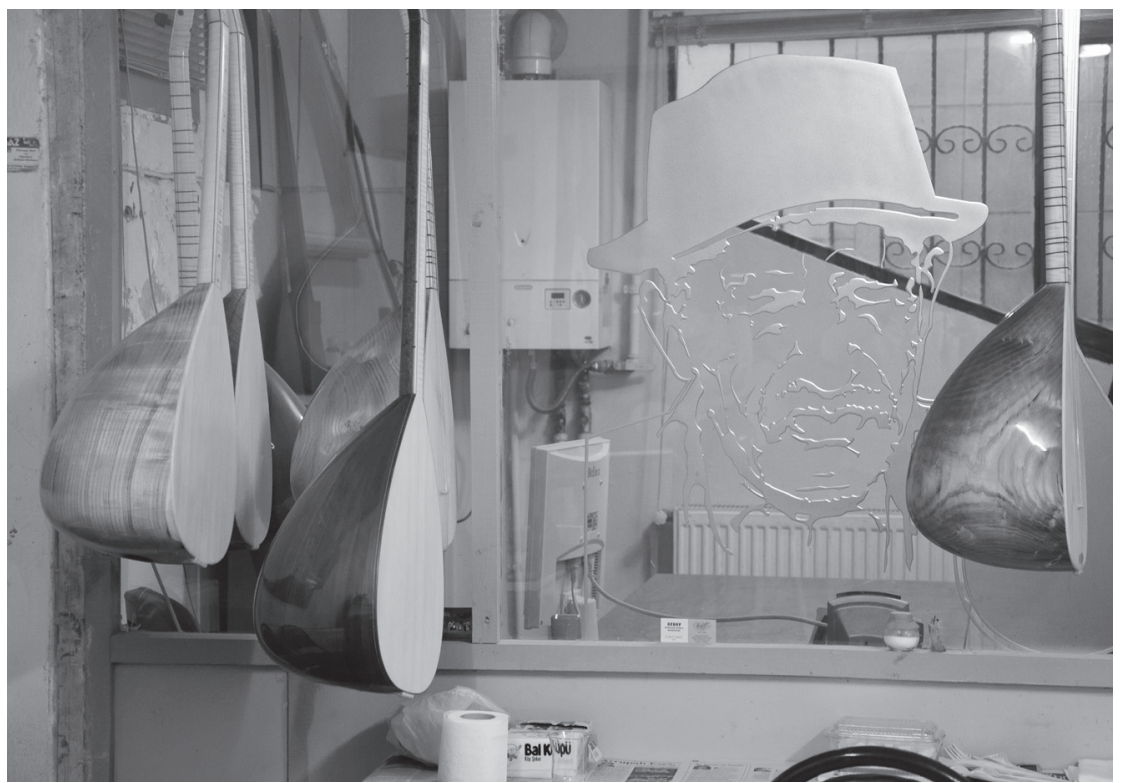

time-consuming, as mulberry is notoriously tricky to work, its hidden knots making it more prone to cracking than other fruitwoods (Figure 3). Despite the price premium, and a potentially negligible difference in sound quality, Özbek Uçar's workshop still fills many orders for carved sazes. Özbek's atölye is similar to the tanbūr workshop of Ustād Asad Allāh described by Hooshmandrad and Fozi; both provide instruments for a steadily increasing worldwide market for sacred instruments, and both continue to use traditional tools and woods.

There is more than one way to make a saz, however. In Özbek's atölye (workshop), he and two other master craftsmen, İlyas Demir and İsmail Akpınar, produce a small number of instruments per month, utilizing many traditional handtools (planes, scrapers, chisels, gouges) and some newer electric machines (band and circular saws, bench grinders). Each of them works on each stage of the construction process. In contrast, in Saz Müzik Aletleri, a saz fabrika (factory) owned by Hasan Sarkkaya, construction is done in more of an assembly-line manner, although nearly all of the work is still done by master craftsmen (and with handtools). ${ }^{34}$ Many of Hasan's employees developed their knowledge and skills in atölye-like environments before becoming fabrika employees, but at the fabrika specialize in one stage of the process: cutting and bending wood staves, planing and truing the saz neck, drilling holes in the pegblock and fitting tuning 


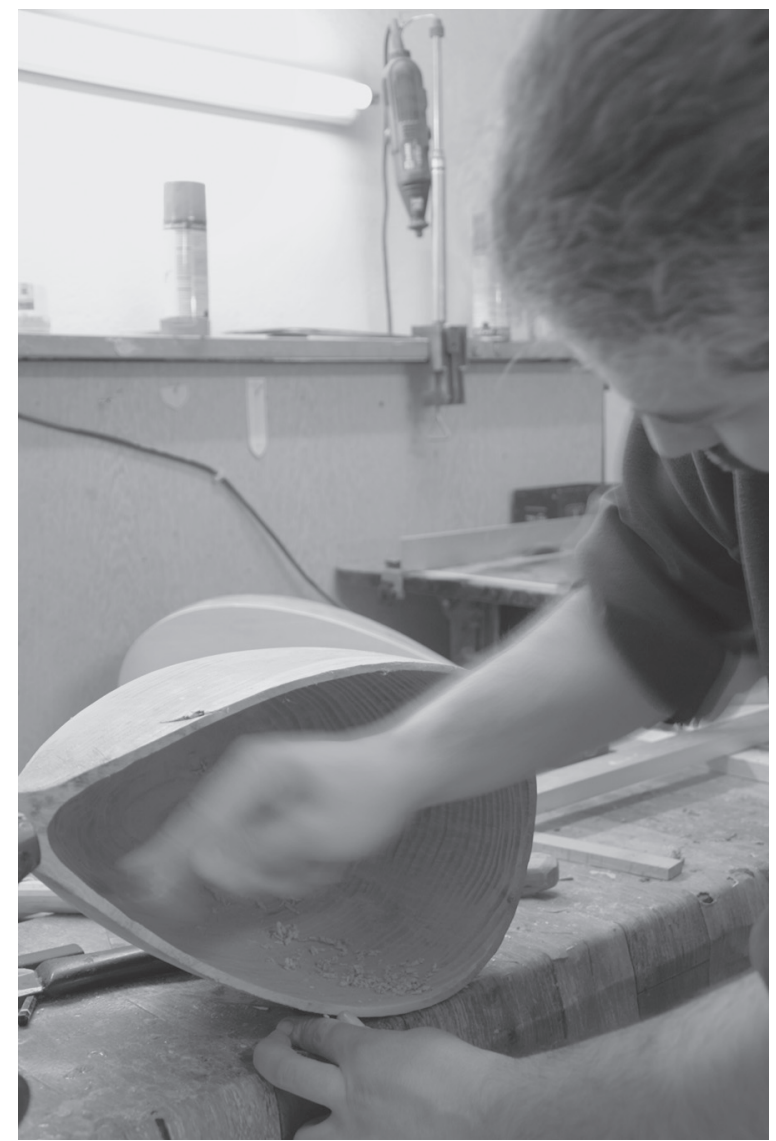

Figure 3. Özkek Uçar handcarving a $s a z$ bowl. Photograph by Ladi Dell'aira.

pegs, or staining and sealing the instruments in polyurethane (Figure 4). In each of these stages, the relationship between maker, saz, and tool changes. When using a bandsaw, the maker moves the wood while the tool remains fixed in place (the bandsaw blade has just enough flex to enable the cutting of curves, but not too much to hinder the cutting of straight lines); when using a handplane, the maker manipulates the tool directly over or through the proto-instrument while it is held firm to the workbench with clamps. At various stages the wood must rest and endure changes in temperature and humidity, otherwise the instrument will continue flexing after it has been assembled. This was most visible at Hasan's fabrika, where the second and third story rooms were filled with upwards of ten thousand sazes in various states of completion (Figure 5). In the tool-centric stages of the process humans appeared to have some degree of control over the wood (although recalling Malafouris's accounts of pottery making, the control 
Figure 4. Hasam Sarkaya's saz fabrika. Photograph by Ladi Dell'aira.

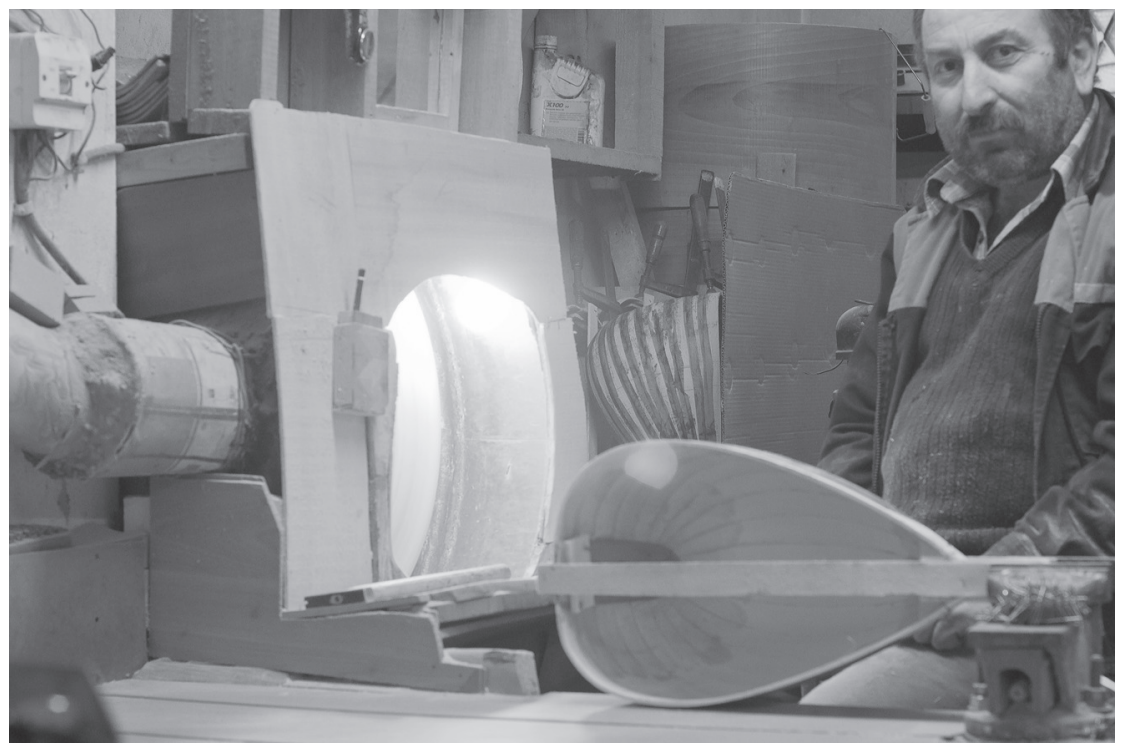

Figure 5. The social life of proto-sazes. Entering this room felt as though I had stumbled upon a private party of sazes, one where no humans were invited. Photograph by Eliot Bates.

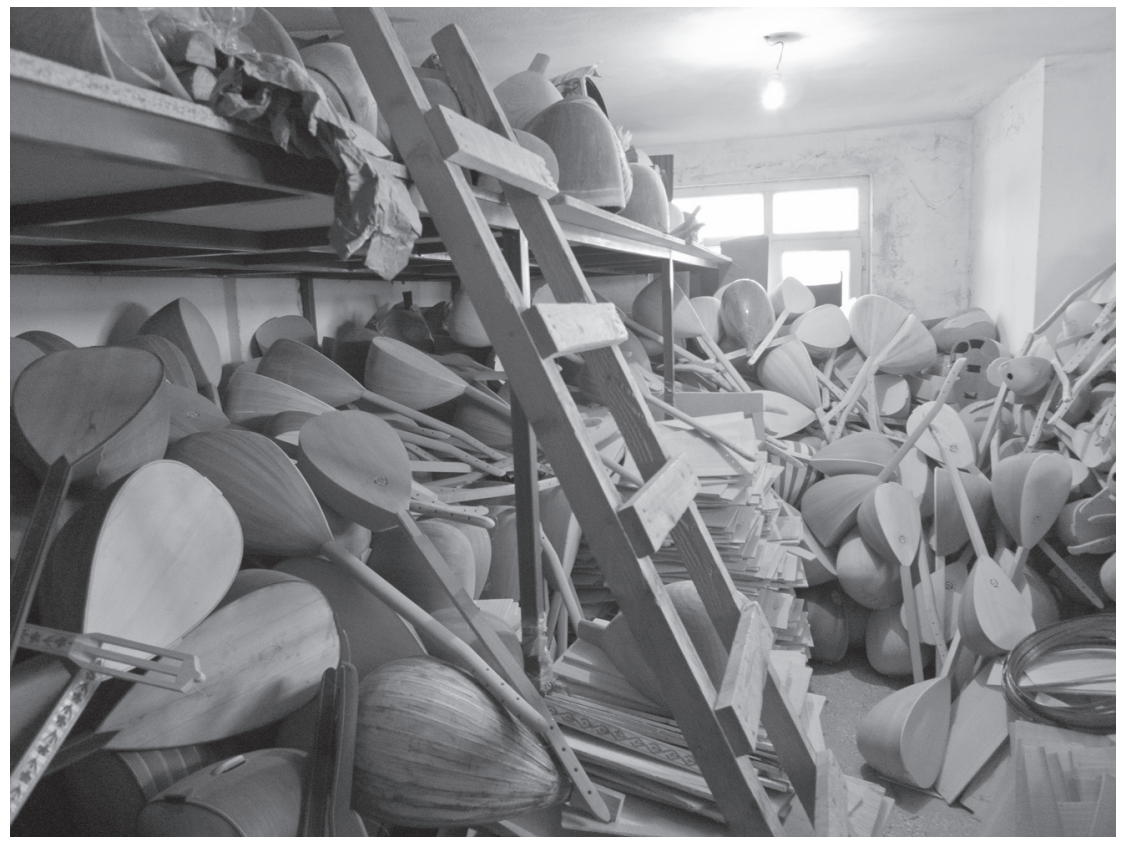


is never complete but rather an example of intention in action), but the resting stage by definition lets nature take its course. Some half-finished sazes warp too much and will not become instruments; others need to have their necks replaned and retrued.

Whereas each instrument from Özbek's atölye results from a unique dialogue between Özbek and the customer, Hasan's shop produces many instruments with the same combination of woods and a standardized playability. For Özbek, construction is a process that is individually negotiated and transpires in relation to his perceived understanding of how the particular instrument may be used by the saz-playing end-user-whether it will be picked, strummed, or played şelpe-style, ${ }^{35}$ and for what kinds of music it will be used. For Hasan, his standardized instrument models are informed by knowledge of thousands of prior maker-customer negotiations and are designed to address the most common concerns. One of Hasan's primary markets is Germany, where there is a large demand for sazes among guestworkers and second-generation TurkishGermans. Expanding on his international ambitions, Hasan hopes to implement a web-based ordering system, where prospective customers choose neck length, tekne (bowl) length, and woods from drag-down menus, designing their own custom instruments without necessitating any face-to-face interaction.

This brings up the issue of the variable mobility of saz instruments, historically and in the present. Așılks such as Dadaloğlu were "wandering minstrels" who travelled Anatolia and Central Asia performing folksongs, popular tales, and oral epics such as the Book of Dede Korkut or Epic of Köroğlu. The aşık profession has existed in name since the fifteenth century (Başgöz 1952), and aşıks nearly always travelled with their sazes, bringing with them music, news from other villages, and of course the crying and troubles of the instrument. ${ }^{36}$ Modern aşıks travel even farther, touring European and North American festival circuits by plane and train. However, not all sazes in historical Anatolia travelled. I have previously mentioned saz-making saz players and their use of local woods. One of their sazes might have experienced its birth, troubles, crying, and eventual death all within a one-mile radius of that first felled tree.

But it is not just the instruments themselves that traverse transnational markets. Many sazes today, including those made in an atölye or fabrika, use exotic woods that would have once been unimaginable. African wenge and zebrawood, Brazilian rosewood, Sri Lankan ebony, and American curly maple often replace the traditional mulberry and chestnut carved bowl, and these exotic materials are sometimes stained in wild colors, such as orange, purple, or green. This is partly due to changing aesthetics, but perhaps more significant is the absence of a sufficient sustainable forestry initiative within Turkey coupled with the ready availability of exotic foreign woods (no matter how rare). Yet, these particular woods gained much value and notoriety, as well as a transoceanic distribution 
network, during the peak of the European colonization of Africa, Oceania, and Central-South America. ${ }^{37}$ In Turkey today, critiques of colonialism, imperialism and transnational capitalism are quite vehement and public, ${ }^{38}$ yet knowledge of the kinds of exploitative labor practices and slash-and-burn decimation of the world's forests that produce the raw materials for new sazes is non-existent. Is the modern saz a key cultural actor whose very existence is made possible by colonial exploitation, cargo ships, and environmental destruction? I'll leave that question unanswered for now.

\section{Saz, Image, and Body}

Like some other stringed instruments, the saz is itself described in humananatomical terms. It has a body (gövde), neck/arm ( $k o l)$, breast ( $g \ddot{g} \ddot{g} \ddot{u s ̧})$, cheek (yanak), and seven ears (kulak), though it is not clear how long this terminology has been used to refer to saz anatomy. But within Alevi history, the saz's anatomy has consistently been related to religious imagery, as the body represents 'Ali, the neck represents 'Alì's sword, and "the 12 strings of the large saz symbolize the 12 imams" (Markoff 1986b:48). In Alevi cem (sacred ceremonies), saz bodies and human bodies come together ritualistically when the dede (religious leader) kisses the saz and touches it to his head before commencing playing (Özdemir 2008). ${ }^{39}$

The most oft-duplicated historical image involving the saz is that of Pir Sultan Abdal (d. 1560), a rural Anatolian martyr who fought against Ottoman authoritarianism and was ultimately hung for his resistance. His poetry lives on as a cornerstone of Anatolian folk literature, and continues to be set to music to this day, particularly in Alevi sacred and secular music practices and by Anatolian rock groups. ${ }^{40}$ However, here we are interested in Pir Sultan's carved kestane (chestnut) saz, which he holds above his head with both hands as if it were a rifle or sword (Figure 6). We have already touched on the endurance of carved bowl designs, but let us now consider the iconography of Pir Sultan in relation to his legendary life and what it might mean to brandish a saz as a weapon. In the hands of Pir Sultan, the saz becomes a weapon against injustice and imperial oppression; he does not even need to play it for its effect to be felt. Perhaps, to invoke a familiar adage, Pir Sultan Abdal implores us to believe that "the saz is mightier than the sword."

Not only Pir Sultan holds the saz in a manner that suggests nonnormative playing techniques. The Turkish-born, Germany-based duo Derdiyoklar, who inaugurated the diskofolk movement of psychedelic-rock- and disco-inspired interpretation of Anatolian folk songs and Alevi secular music, used elektrocura (a small elektrosaz) as part of their own unique form of musical theatre. ${ }^{41}$ Derdiyoklar performed regularly for wedding receptions for German Turks, where their performances included dramatic theatrical suites that moved between heavy 
Figure 6. Pir Sultan Abdal and saz. Photograph by Paul Koerbin. (Used by permission.) (http://koerbin.wordpress.com/2010/10/14)

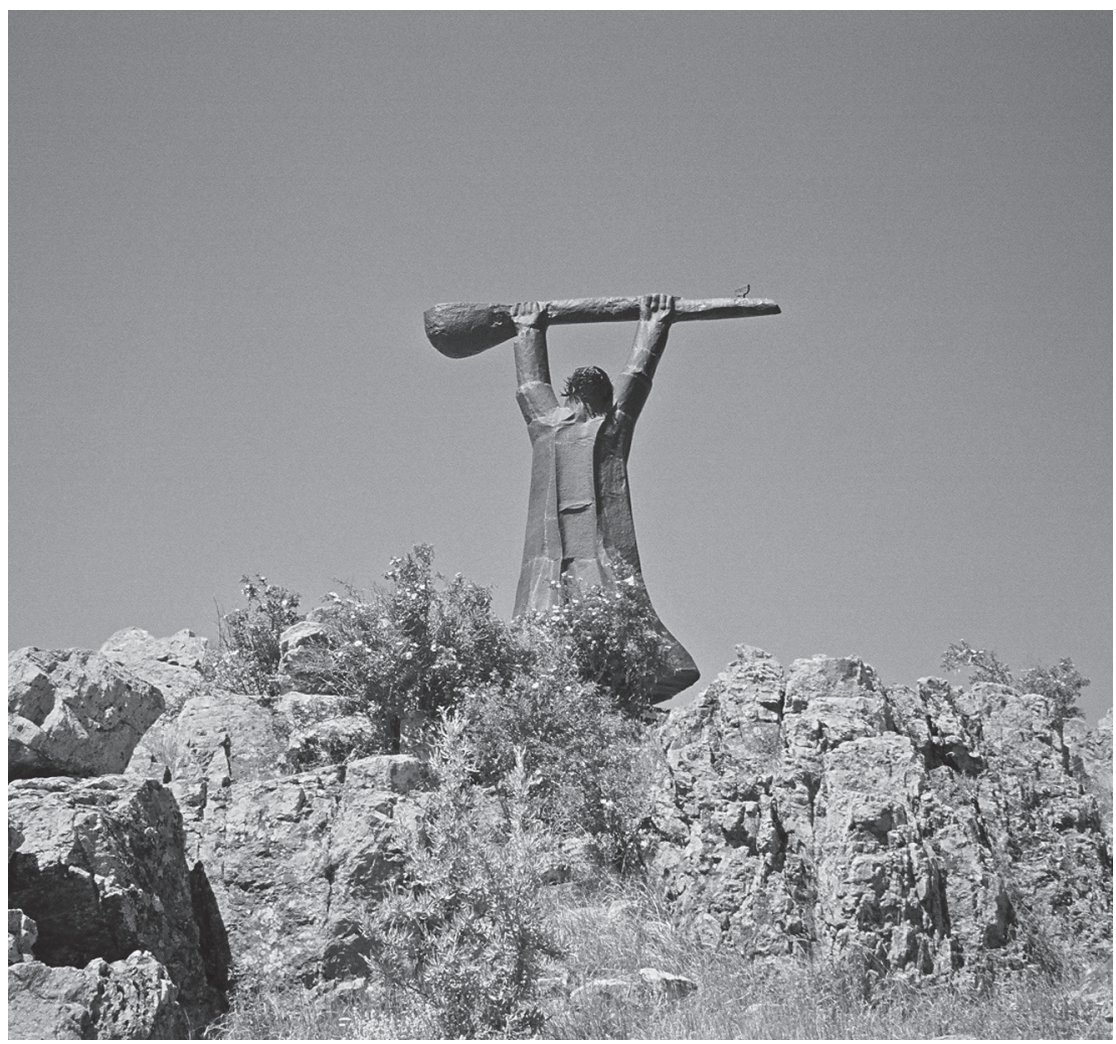

aşık repertoire, experimental improvisations, and drum solos, and culminated in lively line dance numbers. For example, in their 1984-85 performances of Dadaloğlu's “Kalktı göç eyledi avşar elleri (yollar bizimdir)," Ali Ekber Aydoğan interrupted the song lyrics "Belimizde kilıcımız kirmani" (In our mountain pass our swords are broken) with "rifle fire" that he produced sonically, by playing with heavily strumming stopped strings and gesturally mimicking the motions of rifle use with his electrocura. ${ }^{42}$

One night in Ankara, in a restaurant that hosts regular performances of Eastern Anatolian folk music, I sat with several folklore students and the restaurant's proprietor. The subject of why I was interested in Turkish folk music came up, and the proprietor (who remains nameless per his request) started grilling me on why I didn't play music from my own memleket (ancestral homeland), why I played music that wasn't in my own kan (blood). Upon learning that I sang 
türkü and played the oud, an instrument most commonly encountered by Turks today in Ottoman art music ensembles and Kurdish arabesk arrangements and likewise associated with Arabness or multiculturalism but never Turkishness, the proprietor was even more confused. Why didn't I play the saz? After all, if I really wanted to get closer to Turkish music and Turkish people, the saz was the instrument I needed to play. The conversation moved into a general discussion of what would need to happen for me to "become more Turkish" (Türkleşmek). It was agreed that simply by holding, playing, and interacting with a saz I would become more Turkish (although other things might be additionally necessary, such as taking a Turkish surname and converting to Islam). Note that the potential of causation went one way. If I played a saz I wouldn't run the risk of rendering it less Turkish; the saz itself contained an exclusive potentiality to impact change. I encountered similar convictions on numerous occasions-that a repetitive physical practice involving certain musical instruments would unequivocally change me as a person. ${ }^{43}$

The function of saz pedagogy in contemporary Turkish society warrants further attention. Of all the instruments in Turkey, the saz has accumulated the greatest range of pedagogical theories, method books, instructional videos, and private school franchises. As part of the national project, the saz became the key instrument in Turkey, even though it didn't have truly national distribution before the establishment of the Peoples Houses in 1932 and folk music conservatories some years later. Saz pedagogy did not just make foreigners more Turkish, but made modern Turkish citizens more Turkish. Part of the Atatürkian project for national development was the division of rural Anatolia into administrative regions, and we can observe the effects of this in the codification of tavir-regionally defined saz performance practice systems. By learning a set of picking patterns and some standardized repertoire, one "learned" the music of an unfamiliar region. To underscore, it was not conceptual or abstract learning that inculcated a richer sense of Turkishness or regional/national awareness, but rather a kinesthesis, a set of repetitive practices on the saz. Kevin Dawe suggested something similar in describing the lyra as part of the Cretan "body politic" (2007:111) and as "conventionalized by the in-corporation of social meanings where the body becomes imbued with social meanings, norms, values and beliefs" (ibid.:128; emphasis in original).

\section{Conclusion: Questioning Instruments}

I find fascinating the extent to which agentive sazes are implicated in numerous facets of life in contemporary Turkish society, from the ongoing legacies of a Turkish national project to the politicization of minority religious practices to the transformations of craft guilds and transnational lumber industries. Sazes in 
the twentieth and twenty-first centuries are a constituent force in pedagogical projects as much as aesthetic or political ones. Despite the presence of numerous other instruments, the saz continues to wield an immense amount of thingpower, and saz education at private lesson-houses, public educational institutions and conservatories continues to transform the bodies and sensoriums of much of the country's population, perhaps to an even greater extent than compulsory military service and other rituals of the state. ${ }^{44}$ The saz enables Alevi muhabbet and cem ceremonies, and to this day still communicates its troubles to listeners.

My own grappling with the specificity of the social life of the saz, and with questions such as defining what precisely is "national" about "national instruments," led me to a number of rhetorical and practical questions-questions which I hope will contribute to a lived organology that is attentive not just to the vibrancy of living musical styles and musicians, but also to the vibrant life of the material world. Most of these questions could be asked about any specific instrument, and, furthermore, most could be asked about instruments within any heterogeneous network, whether that network operates within a locality, region, nation, diaspora, virtual space, or still-undefined cultural geography. Some questions I have posed, such as "does the performer perform the instrument or the other way around?" may border on the absurd. Yet, the inability to find a consensus regarding this seemingly pedantic question (let us not forget the red violin, green accordion, or the lyrics of numerous türküs) suggests a lingering discomfort and inadequacy with human-centered conceptualizations of "performance" and "agency."

- Why do some musical instruments (but not others) possess the performing musician and/or the audience, and how do such possessions happen?

- Does the performer perform the instrument or the other way around?

- Why are some musical instruments caught in an allegorical web overflowing with symbolism and symbolic associations, while others comparatively seem to lack symbolic references?

- Why are some (but not all) instruments anthropomorphized; for example, being regarded as capable of crying or feeling sorrow?

- Why do some instruments have an instrumental role in moral pedagogy, meaning that simply from the act of repetitively playing them the player becomes a better or worse human being or a subject of the nation?

- In what ways can we understand the effects of "national" instruments not in symbolic or metaphoric terms but as an actual mobilization of a nation?

- Why do some instruments necessitate a "poor" ergonomic position for the performing musician, an ergonomics often leading to permanent injury?

- Why is there a resistance to the adoption of ergonomically "improved" versions of some instruments, and what does that resistance tell us about instrumentperformer relations?

- What sensoriums and kinesthetics are necessary for performers to interact with instruments? What happens in that interaction, and how do certain modes of 
interaction necessitate the cultivation of a specific bodily or sensory pedagogy on the part of the performer?

- Why do some instruments become the site of legal struggles (being banned or restricted in their performance or construction) or even the targets of attack during civil war (as was the case with instrument makers in Iraq in the mid-2000s), while others seem exempt from litigation or conflict?

- Where is the power of sacred instruments located, and how does that sacredness relate (or not relate) to the practices, beliefs and sensoriums of religious experience?

- How do instrument makers relate to the instruments they make at different stages in the making process, and how do those relations themselves relate to the myriad ways in which instrumentalists relate to instruments? Alternately, how does the proto-instrument mediate between instrument maker and user?

- How do makers adapt/respond to changes in the available raw materials, construction tools, and instrumental forms/designs available to them and subsequently alter the way in which instruments are made? How far is too far, or in other words, how much can construction techniques, materials, or formal aspects change without resulting in a new instrument?

Furthermore, I assert that one of the aspects that makes ethnomusicology distinct from other humanistic social sciences is the unique powers and roles of instruments within the lives and studies of both the ethnomusicologists and their interlocutors. For many ethnomusicologists (myself included), instruments alone enable long-term participant observation of a sort and intensity that would be inconceivable in any other social milieu. What might begin as a topical curiosity quickly becomes a vital research implement that (often inadvertently or subconsciously) structures the entire research methodology many of us adopt while in the field. Instrumentality is often implicated in the ethnomusicologist's ability to "understand" a music culture, yet there is rarely any sustained account of how this transference comes to take place..$^{45}$

As I argue for a consideration of musical objects, I also warn against a wholesale march toward a new fetishized "object" (more accurately, topic) of study. One assertion I make in this article is that "the social" has not been adequately studied and theorized because of a paucity of attention given to how social relations are mobilized around material objects and the thing-power that they possess. Likewise, our understanding of "music" can be greatly enriched through an increased understanding of the means of sound production, similarly requiring an attention to objects and instrumentality. Thus, many of the key concerns in ethnomusicology as well as in musicology and numerous branches of anthropology-of the study of music in/as culture-intersect in vital ways with the world of objects.

\section{Acknowledgements}

My research was facilitated by a State Department Fellowship provided by ARIT (American Research Institute in Turkey) (2006-07), a Fulbright IIE grant (2005-06), and an ACLS New Faculty Fellows 
fellowship (2010-12). The idea for this paper emerged during weekly gatherings for Cornell's Society for the Humanities, and I wish to thank its director Timothy Murray, and Society Fellows Michael Jonik, Jolene Rickard, and Lawrence Chua for their provocative questions and encouragement. I thank Larry Witzleben, Andy McGraw, Adam Smith (Cornell), Mustafa Avc1, and Ladi Dell'aira for invaluable feedback on earlier drafts of this article. Additionally, in one or more ways this work benefitted from conversations with Sabahat Akkiraz, Ali Riza Albayrak, Engin Arslan, Aytekin Gazi Ataş, Bob Beer, Necati Çelik, Partow Hooshmandrad, Songül Karahasanoğlu-Ata, Yeliz Keskin, Ayşenur Kolivar, Irene Markoff, Erkan Oğur, Ulaş Özdemir, Trevor Pinch, Hasan Sarıkaya, Özlem Taner, and Özbek Uçar. Finally, I thank Scott Marcus for facilitating my first encounter with an oud and for continued mentorship.

\section{Notes}

1. I also find it interesting that despite Proulx's novel being a bestselling work of "historical fiction," written with a great attention to locality and period-specific dialogue and detail, I could find no published review of the work that lambasted Proulx for allowing so many characters to be possessed by a musical instrument. Such criticisms weren't levied against The Red Violin, either.

2. The golem, in Jewish mythology, was an anthropomorphic being created out of clay and other inanimate objects. In many accounts, a rabbi (and later, in popular fantasy novels, a wizard) creates a golem for a particular purpose, often to protect Jewish society (or the wizard's lab), but loses control of the golem, and the golem subsequently sets on a path of mindless destruction. Golems, unlike other monsters, lack evil intent or the power to possess humans. The golem simply didn't know any better, and its creator didn't understand the nature of what s/he was creating. On the golem and science, see Pinch (2000).

3. In Herman Melville's Pierre: "The guitar was human; the guitar taught me the secret of the guitar; the guitar learned me to play on the guitar. No music-master have I ever had but the guitar ... it knows all my past history ... Bring me the guitar" (1992:125). A similar premise is found in Robert Cezar's novel La Guitarra. I thank Michael Jonik and one anonymous reviewer for these references.

4. I don't intend this primarily as a critique of museum curatorial work. One of the affective powers of instruments is their ability to continue to enchant subsequent generations, even when instruments no longer sound and are contained within protective cases. In a similar vein, Jude Hill writes of how "magic haunts modernity" (2007:72) in relation to British amulets and charms that continue to enchant after being removed from their original context and deposited in museums.

5. The passage on organology in Ethnomusicology: An Introduction expands on Hood's inquiries, suggesting questions collectors could use when collecting a particular instrument (Dournon 1992:290-94). Dournon's list is similar to folksong-collecting questionnaires, and follows a similar functionalist paradigm.

6. Specifically, the Galpin Society Journal, Journal of the American Musical Instrument Society, and the shorter-lived Archiv für Musikorganologie.

7. Ethnomusicologists today refer to the qin as a zither, not a lute, but following Van Gulik I retain his terminological choices in this discussion.

8. For example, despite the broad applicability of DeVale's article, it has yet to be cited in any North American publications or the major European ethnomusicology journals. Also, instruments do continue to be a topic of several national schools; in China and Turkey, many articles, books and musicology dissertations focus on the history and construction of a particular instrument (e.g., Çolakoğlu 2008, Soydaş 2007). These literatures, as well, seem to have a limited circulation.

9. Also noteworthy is Doubleday (2008), a broad survey of prior ethnomusicological work into musical instruments and gender.

10. Dawe is not the first to relate instruments to societal norms. Curt Sachs writes about the evolution of masculine instruments (the trumpet), feminine ones (plucked strings), and how the flute became universally viewed as a "love charm" (1962:94-95). However, Sachs views these as 
symbolic, not constitutive, relations, and does not question the effects of performing gendered instruments.

11. In addition to Dawe's work, other recent publications on metaphoric, symbolic, and analogic meanings of instruments include Kartomi (2005) and Magowan (2005).

12. Ethnomusicological writings on instrumental technique used the terms kinesthetic and kinesthesis as early as 1960, but Baily was arguably the first to treat the topic as the center of analysis. A compelling recent study of the "sensual culture of the guitar," which brings kinesthesis in dialogue with a consideration of affect, is Dawe (2010).

13. John Law writes even more forcibly about this issue: "Artefacts may, indeed, have politics. But the character of those politics, how determinate they are, and whether it is possible to tease people and machines apart in the first instance-these are all contingent questions" (1992:383).

14. For a recent survey of different STS approaches to materiality, see Law (2010).

15. The earliest manifestation of ANT defined an actor as "any element which bends space around itself, makes other elements dependent upon itself and translates their will into a language of its own" (Callon and Latour 1981:286).

16. It was the oud that brought me to Turkey the following year and opened up a path of ethnomusicological inquiry. More accurately, there have been several ouds: the Egyptian oud I borrowed from Scott and the first I bought in Antalya in 1993 were somewhat poor instruments, but their imperfections led me on a long-term search for better instruments and for instruction in Turkish art music performance. Not only specific instruments-but more abstract instrument categories or sensibilities (e.g., the desire to perform oud music) — can be significant actors.

17. Many ethnomusicological works follow the ethnomusicologist's own process of learning an instrument (e.g., Berliner 1993; Rice 1994). While that can be a productive frame, I feel that such works tend to shift the subject to the relation between ethnographer and field, between the scholar and his/her other, a different relation than I'm suggesting in this article.

18. The South Caucasus region includes modern-day Armenia, Azerbaijan, and Georgia. Kurmanc1 and Zazaki are languages in the Northwestern Iranian language family (often lumped together under the moniker "Kurdish language"). Alevi-Bektaşis comprise a heterodox religious sect that adopted elements of Shia Islam; Alevis (who are at the center of this study) are additionally a hereditary ethnicity.

19. An excellent introduction to the saz (and related instruments) in pre-1960s rural Anatolia is Lawrence Picken's Folk Musical Instruments of Turkey (1975).

20. Aşıks are professional folk singers who compose poetry and perform the saz. Historically, aş1ks travelled transnationally and thus were important carriers of news, stories, and saz traditions (Başgöz 2008). Some regions feature aşı competitions and folk-song duels (Erdener 1995).

21. A full analysis of even the poems selected here and their authors is beyond the scope of this work. For an English-language introduction to Turkish folk poetry, see Başgöz (1952) and Başgöz (1998). For more on Ali İzzet Özkan, see Başgöz (1994); on Reyhani, see Kartarı (1977).

22. The türkü "Gene Geldi Yaz Başi” from Rize contains a typical passage, "kemençeyi çalayi kızlar oynayi kızlar" (play the kemençe, make the girls dance). The kemençe doesn’t play itself or possess the owner in such türküs; rather, its sound has an effect. Also perhaps of note: there is no standard term for "saz player" in Turkish, while there are established terms for nearly all other instruments.

23. Neşet Ertaş's autobiographical song "Bin dokuzyüz otuzsekiz cihana" (In 1938 I came into the world) and most trusted biographies cite 1938 as his date of birth. His handwritten autobiography from 1996 lists 1943 as his birth year, but handwriting analysis shows that the original date had been written as "1933," with a "4" superimposed over the first " 3 " with a different pen.

24. Irene Markoff writes about Muharrem Ertaş in her dissertation (1986a).

25. Author Yuksel wrote: "aslında kötü bir adamdır. zira kimsenin beni böyle ağlatmaya hakkı yoktur" (10/19/2005): "anyways he's a bad man, because no one has the right to make me cry like this." http://www.eksisozluk.com/show.asp?t=neşet+ertaş (accessed 15 April 2011). 
26. Irene Markoff notes that the saz is a primary tool in Alevi communities to educate youth about Alevi beliefs and worldviews (personal communication).

27. Irene Markoff (2002) writes of görgü cemi and focuses primarily on the role of the dede (religious leader); the power of the saz in helping enable such reconciliations was a topic of personal communications with Ulaş Özdemir (2006-07) and Dertli Divani (2007).

28. See Kurt (2003) and Ersoy (2011).

29. Lest we overread the language allegory, it is interesting to consider that the Turkish word for language, dil, can also mean tongue (relating to the aşık's words in the song trope saz ve söz), but in Alevi poetry sometimes refers to the heart-an organ that is believed to be essential both for giving and receiving true communication. In Ottoman Turkish compound forms, dil also means heart, such as the Turkish makam suz-i dil-ârâ, meaning "setting the heart on fire."

30. Saz family distinctions are based on the length of the instrument's tekne (bowl). From smallest to largest are the cura (8-12"), dedesaz, tambura, çöğur, and divan (greater than 18.5”). The term bağlama typically refers to tambura and çöğür-sized instruments, and the meydan sazı is a longer divan. Kisa sap refers to shorter-neck versions of a saz. Other common names for saz family members include üçtelli, bam telli, balta, ruzba, and kopuz (Bates 2011:13-15).

31. A thought-provoking recent work on the changing nature of organology and the practices and attitudes of collectors and museum curators is Dawe (2001).

32. I visited Özbek's workshop in the Mecediyeköy neighborhood of Istanbul with Yllmaz Yeşilyurt and Ladi Dell'aira in January 2009; details in this work result from interviews with Özbek and field notes.

33. One interesting instance of government-luthier-consumer interaction was the excavation of an abandoned mine near Turkey's Eastern Black Sea coast. The beams that supported the mine were made of old growth sitka spruce, a kind of wood nearly inaccessible today due to deforestation, yet preferred for the soundboards of ouds, sazes, tanburs, and many other instruments. Oud and saz makers often let their customers know their instruments are made of 100-plus year aged spruce wood from that mine; I own one such oud. Other luthiers employ sitka spruce logs that once were used as fish nets in Alaska and found underwater near riverbanks (MacPherson 1998).

34. Notes about Hasan Sarıkaya and Saz Müzik Aletleri result from an interview in January 2009, informal communications with Bob Beer who works part-time for the firm, and observations of the fabrika in Sarıgazi (an industrial city east of Istanbul) and showroom in Okmeydanı (a neighborhood of Istanbul).

35. Şelpe, also called pençe, is a finger-picking style believed to be the original playing style of the kopuz (the Central Asian predecessor to the saz). The style had largely disappeared in Anatolia, but in the 1970s-80s a number of professional folk musicians (including Hasret Gültekin, Arif Sağ, and Erol Parlak) studied the technique with a performer and saz maker located in Fethiye named Ramazan Güngör (1924-2004) and repopularized it for a national audience.

36. Başgöz traces the history of aşıks to the eleventh century when the profession was known as ozan (poet) and ozans performed the kopuz, a predecessor of the saz (1952:331).

37. For example, Paraguay, a Spanish colony, was "known for its fine hardwood products" as early as the 1600 s, and hardwoods developed into its second largest economic sector by the late 1700s (Cooney 1979:187). A more exhaustive history of colonial and postcolonial deforestation can be found in Williams (2003). One of the few scholarly works to link the international trade in hardwoods with instrument construction is White and Myers's study of woodwind instruments made between 1857 and 1931 by Boosey \& Company (2004).

38. There has yet to be a study of post-1980 political protest in Turkey and the near-daily demonstrations and marches held in Beyoğlu (Istanbul) and on Ankara university campuses. Watts (2010) includes some discussion of anti-imperialism protests but focuses on Kurdish examples.

39. Ulaş Özdemir has conducted long-term research into the sacred-secular dichotomy of sazes in Alevi-Bektaşism, which will hopefully provide much richer detail about the embodied nature and sacred registers of the saz. 
40. For a general introduction to Alevi musical practices, see Markoff (1986b). For a an-depth discussion of Pir Sultan's legacy in contemporary Alevi expresssive performance, see Koerbin (2011).

41. See Stokes (1992) for more on electrified saz instruments.

42. Videos of Derdiyoklar's 1980s performances at German weddings abound on YouTube and other video sharing websites.

43. The tanbur used in Ottoman art music is another instrument framed in relation to physical discipline and moral pedagogy. While the saz is capable of imparting Turkishness, the tanbur is capable of bringing moral piety, and as such has seen a renaissance among some of the more observant Muslim youth in Istanbul. The 'ûd and ney are also often viewed in this manner and all three are often regarded as tasavvuf instruments, yet the tanbur is the only one to be considered quintessentially Turkish, the oud being of Arab and the ney of Persian origin.

44. Here I am thinking of Yael Navaro-Yaşin's anthropological study on secularism and public life in Turkey, where she analyzes wrestling, flag campaigns, holidays, and military service sendoffs as constituent elements of a broader project of public statism (2002).

45. Most of the contributions to Solís's collection Performing Ethnomusicology suggest that the kinesthetic practice of playing musical instruments can lead to conceptual understanding, including David Harnish's discussion of the Balinese concept of guru panggul, or "teacher mallet" (2004:132). Similar instrument references permeate many contributions to the second edition of Barz and Cooley's collection Shadows in the Field (2008). Despite the central importance of musical instruments in both volumes, "musical instruments" or "instruments" do not appear as index entries, nor is there any explicit theorization of precisely how kinesthetic practice leads to conceptual understanding.

\section{References}

Appadurai, Arjun. 1986. The Social Life of Things: Commodities in Cultural Perspective. Cambridge: Cambridge University Press.

Baily, John. 1976. "Recent Changes in the Dutār of Herat.” Asian Music 8(1):29-64.

— 1977. "Movements in Playing the Herati Dutār." In Anthropology of the Body, edited by John Blacking, 275-330. London: Academic Press. 1988. Music of Afghanistan: Professional Musicians in the City of Herat. Cambridge: Cambridge University Press.

Barz, Gregory, and Timothy Cooley, eds. 2008. Shadows in the Field: New Perspectives for Fieldwork in Ethnomusicology. Second Edition. New York: Oxford University Press.

Başgöz, İlhan. 1952. “Turkish Folk Stories about the Lives of Minstrels.” Journal of American Folklore 65(258):331-39. .1994. Âşık Ali İzzet Özkan. Istanbul: Pan Yayıncilık. . 1998. Turkish Folklore and Oral Literature: Selected Essays of İlhan Başgöz. Bloomington: Indiana University.

—. 2008. Hikâye: Turkish Folk Romance as Performance Art. Bloomington: Indiana University Press.

Bates, Eliot. 2011. Music in Turkey: Experiencing Music, Expressing Culture. New York: Oxford University Press.

- Forthcoming. Digital Tradition: Arranging and Engineering Traditional Music in Turkey.

Bennett, Jane. 2010. Vibrant Matter: A Political Ecology of Things. Durham, NC: Duke University Press.

Berliner, Paul. 1993. The Soul of the Mbira: Music and Traditions of the People of Zimbabwe. Chicago: University of Chicago Press.

Bijker, Wiebe E. 1995. Of Bicycles, Bakelite and Bulbs: Toward a Theory of Sociotechnical Change. Cambridge, MA: MIT Press.

Bijsterveld, Karin, and Marten Schulp. 2004. "Breaking into a World of Perfection: Innovation in Today's Classical Musical Instruments.” Social Studies of Science 34(5):649-74. 
Callon, Michel, and Bruno Latour. 1981. "Unscrewing the Big Leviathan: How Actors Macrostructure Reality and How Sociologists Help Them Do So." In Advances in Social Theory and Methodology: Towards an Integration of Micro and Macro-Sociology, edited by Karin KnorrCetina and Aaron Cicourel, 277-303. Boston: Routledge.

Cezar, Robert. 2005. La Guitarra: An Autobiography of a Guitar. Bloomington: AuthorHouse.

Cooney, Jerry. 1979. "Forest Industries and Trade in Late Colonial Paraguay." Journal of Forest History 23(4):186-97.

Çolakoğlu, Gözde. 2008. “Anadolu’dan Balkanlara Armudi Biçimindeki Kemençeler: Tarih, Teknik ve Geleneksel İcrasına İliş̧kin Karşılaştırmalı Bir Analiz” (Pear-shaped kemençes from Anatolia to the Balkans: a comparative analysis of history, technique, and traditional performance connections). Ph.D. Dissertation, Istanbul Technical University.

Dawe, Kevin. 2001. "People, Objects, Meaning: Recent Work on the Study and Collection of Musical Instruments." Galpin Society Journal 54:219-32.

—. 2005. "Symbolic and Social Transformation in the Lute Cultures of Crete: Music, Technology and the Body in a Mediterranean Society." Yearbook for Traditional Music 37:58-68.

- 2007. Music and Musicians in Crete: Performance and Ethnography in a Mediterranean Island Society. Lanham, MD: Scarecrow Press.

- 2010. The New Guitarscape in Critical Theory: Cultural Practice and Musical Performance. Farnham: Ashgate.

DeVale, Sue Carole. 1988. "Musical Instruments and Ritual: A Systematic Approach." Journal of the American Musical Instrument Society 5:89-123.

— 1990. "Organizing Organology." Selected Reports in Ethnomusicology 8:1-34.

Doubleday, Veronica. 2008. "Sounds of Power: An Overview of Musical Instruments and Gender." Ethnomusicology Forum 17(1):3-39.

Dournon, Geneviève. 1992. "Organology." In Ethnomusicology: An Introduction, edited by Helen Myers, 245-300. London: Norton.

Erdener, Yildiray. 1995. The Song Contests of Turkish Minstrels: Improvised Poetry Sung to Traditional Music. London: Taylor and Francis.

Ersoy, İlhan. 2011. "Türkiyede Uluslaşma Sürecinde Bir Simgi Olarak 'Bağlama”' ("Bağlama” as a symbol in the process of Turkish nation-building). http://www.musikidergisi.net/?p=1271 (accessed April 2012).

Falkner, J. Meade. 1895. The Lost Stradivarius. New York: Penguin. Available at www.gutenberg.org/ ebooks/14107 (accessed April 2012).

Fozi, Navid. 2007. "The Hallowed Summoning of Tradition: Body Techniques in Construction of the Sacred Tanbur of Western Iran." Anthropological Quarterly 80(1):173-205.

Gell, Alfred. 1998. Art and Agency. London: Clarendon Press.

Hill, Jude. 2007. "The Story of the Amulet: Locating the Enchantment of Collections." Journal of Material Culture 12(1):65-87.

Hood, Mantle. 1982. The Ethnomusicologist. Revised edition. Kent, OH: Kent State University Press.

Hooshmandrad, Partow. 2004. "Performing the Belief: Sacred Musical Practice of the Kurdish Ahl-i Haqq of Gūrān.” Ph.D. Dissertation, University of California, Berkeley.

Hornbostel, Erich M. von, and Curt Sachs. 1961. "Classification of Musical Instruments." Translated by A. Baines and K. Wachsmann. The Galpin Society Journal 14:3-29.

Kartarı, Hasan. 1977. Doğu Anadolu'da Âsık Edebiyatının Esasları (Works of aşık literature in Eastern Anatolia). Ankara: Demet Matbaacillk.

Kartomi, Margaret. 2005. "On Metaphor and Analogy in the Concepts and Classification of Musical Instruments in Aceh." Yearbook for Traditional Music 37:25-57.

Koerbin, Paul. 2011. "I Am Pir Sultan Abdal': A Hermeneutical Study of the Self-Naming Tradition (Mahlas) in Turkish Alevi Lyric Song (Deyiş)." Ph.D. Dissertation, University of Western Sydney.

Kurt, İrfan. 2003. "Bağlama ve Bağlama Ailesinin Tanımlanmasındaki Sorunlar" (Problems in 
defining the bağlama and the bağlama family). Türkü Sitesi. http://www.turkuler.com/yazi/ baglamavebaglama.asp (accessed April 2012).

Latour, Bruno. 1996. "On Actor-Network Theory: A Few Clarifications." Soziale Welt 47(4):369-81.

Latour, Bruno, and Steve Woolgar. 1979. Laboratory Life: The Social Construction of Scientific Facts. Beverley Hills: Sage.

Law, John. 1992. "Notes on the Theory of the Actor-Network: Ordering, Strategy, and Heterogeneity." Systems Practice 5(4):379-93.

_ 2010. "The Materials of STS." In The Oxford Handbook of Material Culture Studies, edited by Dan Hicks and Mary Beaudry, 173-88. Oxford: Oxford University Press.

MacPherson, James. 1998. "Best Guitar Wood Found in SE Forests." Daily Sitka Sentinel (Sitka, Alaska), November 4:6.

Magowan, Fiona. 2005. "Playing with Meaning: Perspectives on Culture, Commodification and Contestation around the Didjeridu." Yearbook for Traditional Music 37:80-102.

Mahillon, Victor-Charles. 1880. Catalogue descriptif et analytique du Musée instrumental du Conservatoire Royal de Musique du Bruxelles. Ghent: Libraire Générale de Ad. Hoste.

Malafouris, Lambros. 2008. "At the Potter's Wheel: An Argument for Material Agency." In Material Agency: Towards a Non-Anthropocentric Approach, edited by Carl Knappett and Lambros Malafouris, 19-36. New York: Springer.

Markoff, Irene. 1986a. "Musical Theory, Performance and the Contemporary Bağlama Specialist in Turkey." Ph.D. Dissertation, University of Washington.

- 1986b. "The Role of Expressive Culture in the Demystification of a Secret Sect of Islam: The Case of the Alevis of Turkey." The World of Music 28(3):42-56.

_ 1993. "Music, Saints, and Ritual: Sama' and the Alevis of Turkey." In Manifestations of Sainthood in Islam, edited by G. M. Smith and C. W. Ernst, 95-110. Istanbul: The Isis Press.

_. 2002. "Alevi Identity and Expressive Culture." In The Garland Encyclopedia of World Music. Volume 6: The Middle East, edited by Virginia Danielson, Scott Marcus, and Dwight Reynolds, 789-92. New York: Routledge.

Melville, Herman. [1852] 1992. Pierre; Or, The Ambiguities. Evanston, IL: Northwestern University Press.

Miller, Daniel, ed. 1998. Material Cultures: Why Some Things Matter. Chicago: University of Chicago Press.

Navaro-Yashin, Yael. 2002. Faces of the State: Secularism and Public Life in Turkey. Princeton, NJ: Princeton University Press.

Özdemir, Ulaş. 2008. "Ancient Sound of Anatolia: The Baglama." http://www.setar.info/index .php? view $=$ articlee $r i d=66$ (accessed April 2012).

Pels, Dick, Kevin Hetherington, and Frédéric Vandenberghe. 2002. "The Status of the Object: Performances, Mediations, and Techniques." Theory, Culture \& Society 19(5/6):1-21.

Picken, Laurence Ernest Rowland. 1975. Folk Musical Instruments of Turkey. London: Oxford University Press.

Pinch, Trevor. 2000. "The Golem: Uncertainty and Communicating Science." Science and Engineering Ethics 6(4):511-23.

- 2008. "Technology and Institutions: Living in a Material World." Theory and Society 37(5):46183.

Pinch, Trevor, and Frank Trocco. 2002. Analog Days: The Invention and Impact of the Moog Synthesizer. Cambridge, MA: Harvard University Press.

Proulx, E. Annie. 1996. Accordion Crimes. New York: Scribner.

Qureshi, Regula. 2000. "How Does Music Mean? Embodied Memories and the Politics of Affect in the Indian Sarangi." American Ethnologist 27(4):805-38.

Rice, Timothy. 1994. May it Fill Your Soul: Experiencing Bulgarian Music. Chicago: University of Chicago Press. 
Riggins, Stephen Harold. 1994. The Socialness of Things: Essays on the Socio-semiotics of Objects. Berlin: Mouton de Gruyter.

Sachs, Curt. 1962. The Wellsprings of Music. The Hague: Martinus Nijhoff.

Slobin, Mark. 1969. Kirgiz Instrumental Music. New York: Society for Asian Music.

— . 1976. Music in the Culture of Northern Afghanistan. Viking Fund Publications in Anthropology. Tucson: University of Arizona Press.

Solís, Ted, ed. 2004. Performing Ethnomusicology: Teaching and Representation in World Music Ensembles. Berkeley: University of California Press.

Soydaş, Emin. 2007. "Osmanlı Sarayında Çalgılar" (Instruments in the Ottoman Court). Ph.D. Dissertation, Istanbul Technical University.

Stokes, Martin. 1992. "The Media and Reform: The Saz and Elektrosaz in Urban Turkish Folk Music." British Journal of Ethnomusicology 1:89-103.

Straw, Will. 1991. "Systems of Articulations, Logics of Change: Communities and Scenes in Popular Music." Cultural Studies 5(3):368-88.

Théberge, Paul. 1997. Any Sound You Can Imagine: Making Music / Consuming Technology. Hanover: Wesleyan University Press.

Tokel, Bayram Bilge. 2007. "Neşet Ertaş: Ünlülerin Görüşleri” (Neşet Ertaş: the views of wellrenowned people). http://zahidem.blogspot.com/2007/08/df.html (accessed April 2012)

Turnbull, Harvey. 1972. "The Origin of the Long-necked Lute." Galpin Society Journal 25:58-66.

Van Gulik, R. H. 1969. The Lore of the Chinese Lute: An Essay in the Ideology of the Ch'in. Revised edition. Tokyo: Monumenta Nipponica.

Vannini, Phillip, ed. 2009. Material Culture and Technology in Everyday Life: Ethnographic Approaches. New York: Peter Lang.

Watts, Nicole. 2010. Activists in Office: Kurdish Politics and Protest in Turkey. Seattle: University of Washington Press.

White, Kelly, and Arnold Myers. 2004. "Woodwind Instruments of Boosey \& Company." Galpin Society Journal 57:62-80.

Williams, Michael. 2003. Deforesting the Earth: From Prehistory to Global Crisis. Chicago: University of Chicago Press.

Woodward, Ian. 2009. "Material Culture and Narrative: Fusing Myth, Materiality, and Meaning." In Material Culture and Technology in Everyday Life: Ethnographic Approaches, edited by Phillip Vannini, 59-72. New York: Peter Lang. 